\title{
Hubungan Pengetahuan Ibu Tentang Pola Makanan Balita Dengan Status Gizi Balita di Rumah Sakit TK. II Putri Hijau Medan
}

\author{
Resmi Pangaribuan ${ }^{1}$, Marliani $^{2}$, \\ ${ }^{1}$ Akper Kesdam I/BB Medan, ${ }^{2}$ Stikes Mitra Husada Medan \\ email: ${ }^{1}$ resmi.pangaribuan131417@gmail.com, ${ }^{2}$ marlianidady@gmail.com
}

\begin{abstract}
ABSTRAK
Gizi seimbang adalah susunan makanan sehari-hari yang mengandung zat gizi dalam jenis dan jumlah yang sesuai dengan kebutuhan tubuh yaitu jenis kelamin, umur dan status kesehatan. Pola makan yang tidak bergizi seimbang beresiko menyebabkan kekurangan gizi seperti anemia dan berat badan kurang, dapat pula terjadi gizi berlebih (obesitas) yang dapat beresiko terjadinya penyakit degeneratif seperti hipertensi, penyakit jantung koroner dan diabetes melitus. Tujuan penelitian yaitu untuk mengetahui hubungan pengetahuan ibu tentang Pola Makanan balita dengan Status Gizi balita di Rumah Sakit Tk II Putri Hijau Medan, Jenis penelitian ini bersifat deskriprtif korelatif dengan rancangan study cross sectional. Populasi dalam penelitian ini yaitu seluruh ibu yang mempunyai balita yang datang ke poliklinik anak sebanyak 135 orang dan sampel yaitu total dari populasi. Analisa data menggunakan uji statistic chi square. Hasil penelitian menunjukkan ada hubungan Pengetahuan Ibu Tentang Pola Makanan Balita dengan Status Gizi Balita dimana nilai $p=0,000$ dan ada husbungan pengetahuan ibu tentang jenis makanan tentang status gizi balita dimana nilai $\mathrm{p}=0,004$. Dari hasil penelitian dapat disimpulkan bahwa ada hubungan pengetahuan ibu tentang pola makan balita dengan status gizi balita dimana nilai $p=0,003$. Disarankan kepada ibu-ibu untuk tetap memperhatikan pola makan balita untuk meningkatkan status gizi balitanya.
\end{abstract}

Kata kunci: Pengetahuan Ibu, Pola Makanan Balita, Status Gizi Balita

\section{Relationship of Mother Knowledge About Children Food Patterns With Toddler Nutrition Status In Putri Hijau Medan Hospital}

\begin{abstract}
Balanced nutrition is a daily diet that contains nutrients in the type and amount that is in accordance with the body's needs for sex, age and health status. A diet that is not nutritionally balanced is at risk of causing malnutrition such as anemia and underweight, it can also occur over nutrition (obesity) which can be at risk of overcoming degenerative diseases such as hypertension, coronary heart disease and diabetes mellitus. The purpose of this research is to study the relationship between mothers about toddlers' dietary patterns and nutritional status of toddlers at TK Hijau Putri Medan Hospital, Medan. This type of research is correlative descriptive by making cross sectional studies. The population in this study are all mothers who have children who come to the polyclinic of children as many as 135 people and the total number of samples from the population. Data analysis using chi square statistical tests. The results showed that there was a relationship between Mother's Knowledge of Toddler Food Patterns and Toddler Nutrition Status where the value of $p=0,000$ and there was a correlation of mother's knowledge about the type of food about the nutritional status of children with a value of $p=0.004$. From the results of this study it can be concluded that there is a relationship between mother's knowledge about toddler's eating patterns with toddler's nutritional status where the p value $=0.003$. More about mothers to still pay attention to toddler's diet to improve the nutritional status of their toddlers.
\end{abstract}

Keywords: Mother's Knowledge, Toddler Food Patterns, Toddler Nutrition Status 


\section{PENDAHULUAN}

Gizi adalah zat makanan pokok yang diperlukan bagi pertumbuhan dan kesehatan tubuh. Gizi seimbang adalah susunan makanan sehari-hari yang mengandung zat gizi dalam jenis dan jumlah yang sesuai dengan kebutuhan tubuh yaitu jenis kelamin, umur dan status kesehatan. Pola makan yang tidak bergizi seimbang beresiko menyebabkan kekurangan gizi seperti anemia dan berat badan kurang, dapat pula terjadi gizi berlebih (obesitas) yang dapat beresiko terjadinya penyakit degeneratif seperti hipertensi, penyakit jantung koroner dan diabetes melitus. Hal terburuk dari kekurangan gizi akan menyebabkan efek yang sangat serius sepeti kegagalan pertumbuhan fisik, menurunkan IQ, menurunnya produktivitas, menurunnya daya tahan tubuh terhadap penyakit serta meningkatkan reiko penyakit dan kematian (dr. Sentot Handoko, Sp.GK, 2020).

Hal terburuk akibat dari kekurangan gizi bagi balita adalah balita akan menderita penyakit kwashiorkor (busung lapar karena kekurangan progtein) dan marasmus (kekurangan kalori). Jika balita menderita kwashiorkor dapat mengakibatkan daya tahan tubuh balita rendah dan mudah terserang berbagai jenispenyakit seperti pembesearah hati disertai infeksi, anemia diare dan TBC. Jika terserang marasmus balita dapat menderita diare kronik. Dampak jangka panjang yang muncul pada balita yang kurang gizi adalah pertumbuhan dan perkembangan balita terganggu, gangguan kecerdasan dan menurunkan kualitas sunber daya manusia. Perlu diperhatikan Indek masa Tubuh balita dan berat badan ideal anak untuk ditarik kesimpulan kebutuhan nutrisi nya kurang ata tidak dengan menggunakan rumus/ketentan (Pangaribuan R, 2018:100).

Sensus WHO pada tahun 2007 menunjukkan 30 juta kematian pada balita dinegara berkembang berkaitan dengan kekurangan gizi. Kasus kekeurangan gizi yang terjadi dibeberapa Negara berkembang sebanyak 30 juta balita, seperti di India sebanyak 14 juta balita mengalami kekurangan gizi di Cina sebanyak 6 juta balita mengalami kekurangan gizi, di Asia sebanyak 5 juta balita mengalami kekurangan gizi dan di Afrika sebanyak 3 juta balita mengalami kekurangan gizi dan di Amerika Latin Sebanyak 2 juta balita mengalami kekurangan gizi (Moris, 2008).

Menurut hasil Riskesdas (2013) diketahui bahwa gizi kurang di Indonesia sebesar 19,6\% dan di Provinsi Sulawesi Tenggara angka gizi kurang ini lebih besar yakni sebesar 23,9\%. Sedangkan dalam riset yang sama prevalensi di Kabupaten Konawe Seletan sebesar 17,9\%. Berdasarkan data yang diperoleh pada Puskesmas Lameuru jumlah ibu yang mempunyai balita tahun 2016 sebanyak 235 orang.

\section{TINJAUAN PUSTAKA \\ Pengetahuan}

Pengetahuan merupakan hasil tahu seseorang terhadap suatu obyek tertentu melalui indera yang dimilikinya. Pengetahuan kognitif merupakan faktor yang sangat penting untuk terbentuknya tindakan seseorang, sebab dari pengalaman dan hasil penelitian terenyata perilaku yang didasari oleh pengetahuyan akan lebih langgeng daripada perilaku yang tidak didasari oleh pengetahuan (Notoatmodjo, S, ).

\section{Tingkatan Pengetahuan Dalam Domain Kognitif}

Pengetahuan atau kognitif merupakan domain yang sangat penting dalam membentuk tindakan seseorang (over behavior). Pengetahuan seseorang terhadap suatu obyek mempunhyai intensitas atau tingkat yang berbeda-beda. Evaluasi (evaluation)

\section{Faktor-Faktor Yang Mempengaruhi Pengetahuan}

Ada beberapa hal yang dapat memepengaruhi pengetahuan, yaitu sebagai berikut: Umur, Pendidikan, Pekerjaan, Informasi 


\section{Pola Makan}

Menurut dr. Sentot Handoko, Sp.GK (2020), Pola makan yang tidak bergizi seimbang beresiko menyebabkan kekurangan gizi seperti anemia dan berat badan kurang, dapat pula terjadi gizi berlebih (obesitas) yang dapat beresiko terjadinya penyakit degeneratif seperti hipertensi, penyakit jantung koroner dan diabetes melitus.

\section{Pola Makan Balita}

Agar pola makan balita baik dapat terbentuk dengan baik, pedoman praktis untuk membentuk dan menjaga pola makan yang sehat pada balita

\section{Frekuensi Makan}

Frekuensi makan sehat adalah kebiasaan makan yang dilakukan sesuai dengan metabolism tubuh. Pemberian makana pada balita dilakukan dalam waktu yang sering.

\section{Porsi Makan}

Porsi makanan yang dianjurkan pada balita dalam sehari sebagai sumber zat tenaga sebanyak 3-4 piring nasi (piring kecil balita), sebagai sumber zat pembangun sebanyak 4-5 porsi lauk ( 1 porsi lauk $=50$ gram $)$, terdapat dalam satu potong sedang ikan segar, 2 sendok makan ikan teri, 2 potong daging, 1 butir telur, 1 biji tahu dan 2 potong edang tempe), sebagai sumber zat pengatur sebanyak 2-3 mangkuk sayuran dan buah-buahan (alpukat 1/2 buah besar, apel $1 / 2$ buah sedang, jeruk 2 buah sedang, papaya 1 potong sedang, pisang ambon 1 buah sedang, semangka 1 potong besar, dan jambu biji 1 buah besar) yang diberikan sehabi makan siang dan makan malam. Bila porsi makanan utama yang dikonsumsi balita pada saat makan pagi hari, siang dan malam hari belum mencukupi, maka sangat diperlukan pemberian selingan seperti bubur sebanyak 1 sendok makan kecil atau roti sebanyak 5 potong.

\section{METODE PENELITIAN}

\section{Jenis Penelitian}

Jenis penelitian yang digunakan adalah penelitian deskriptif koleratif dengan rancangan study cross sectional yang bertujuan untuk mengetahui hubungan pengetahuan ibu tentang pola makanan balita dengan Status Gizi di Rumah sakit Tk. II Putri Hija Medan. Populasia adapun yang menjadi populasi dalam penelitian ini adalah seluruh ibu yang mempunyai balita sebanyak 135 orang. Analisis Data menggunakan analisis univariat dan analisis bivariat. Analisis univariat digunakan untuk mengetahahui distribusi frekuensi dan persentase dari masing-masig variabel bebas dan variabel terikat. Analisis bivariat digunakan untuk mengidentifikasi hubungan pengetahuan ibu tentang pola makan balita dengan status gizi balita dengan uji kolerasi chi square. Signifikasi hubungan dua variabel dapat dianalisis dengan ketentan nilai $\mathrm{p}$ $<0,05$ hubungan signifikan jika nilai $\mathrm{p}>0,05$ hbngan tidak signifikan. 


\section{HASIL DAN PEMBAHASAN}

Hasil Penelitian

Deskripsi Karakteristik Responden

Distribusi Frekuensi Menurut Umur

Dari tabel 1 dibawah ini menunjukkan bahwa umur ibu mayoritas berumur 30-39 tahun sebanyak $51,9 \%$.

Tabel 1. Distribusi frekuensi umur ibu yang memiliki balita di Rumah Sakit TK. II Putri Hijau Medan

\begin{tabular}{|c|c|c|c|}
\hline No & Umur & Frekuensi & Persentase $(\%)$ \\
\hline 1 & $20-29$ & 50 & $37.0 \%$ \\
\hline 2 & $30-39$ & 70 & $51.9 \%$ \\
\hline 3 & $40-49$ & 15 & $11.1 \%$ \\
\hline \multicolumn{2}{|c|}{ Total } & 135 & $100.0 \%$ \\
\hline
\end{tabular}

Distribusi Frekuensi Pendidikan

Tabel 2 Distribusi frekuensi Pendidikan ibu yang mamiliki balita di Rumah Sakit Tk II Putri hijau Medan

\begin{tabular}{cccc} 
No & Pendidikan & Frekuensi & Persentase (\%) \\
\hline 1 & SD & 91 & $67.4 \%$ \\
2 & SMP & 32 & $23.7 \%$ \\
3 & SMA & 11 & $8.1 \%$ \\
4 & SARJANA & 1 & $0.7 \%$ \\
\hline \multicolumn{4}{c}{ Total } \\
\hline
\end{tabular}

Distribusi frekuensi menurut pekerjaan

Tabel 3 Distribusi frekuensi pekerjaan ibu yang memiliki balita di Rumah Sakit TK. II Putri Hijau Medan

\begin{tabular}{cccc} 
No & Pekerjaan & Frekuensi & Persentase (\%) \\
\hline 1 & Petani & 133 & $98.5 \%$ \\
2 & Wiraswasta & 1 & $0.7 \%$ \\
3 & PNS & 1 & $0.7 \%$ \\
\hline & Total & $\mathbf{1 3 5}$ & $\mathbf{1 0 0 . 0 \%}$ \\
\hline
\end{tabular}

Distribusi pengetahuan ibu tentang frekuensi makan

Tabel 4 Distribusi frekuensi pengetahuan ibu tentang frekuensi makan di Rumah Sakit TK. II Putri Hijau Medan

\begin{tabular}{cccc}
\hline No & Frekwensi Makan & Frekuensi & Persentase (\%) \\
\hline 1 & Kurang & 38 & $28.1 \%$ \\
2 & Cukup + Baik & 97 & $71.9 \%$ \\
\hline & Total & $\mathbf{1 3 5}$ & $\mathbf{1 0 0 . 0 \%}$ \\
\hline
\end{tabular}


Deskripsi Pengetahuan Ibu Tentang Porsi Makanan

Tabel 5 Distribusi Frekuensi Pengetahuan Ibu Tentang Porsi Makanan Di Rumah Sakit TK. II Putri Hijau Medan

\begin{tabular}{cccc} 
No & Porsi Makan & Frekuensi & Persentase (\%) \\
\hline 1 & Kurang & 47 & $34.8 \%$ \\
2 & Cukup + Baik & 88 & $65.2 \%$ \\
\hline & Total & $\mathbf{1 3 5}$ & $\mathbf{1 0 0 . 0 \%}$ \\
\hline
\end{tabular}

Deskripsi Pengetahuan Ibu Tentang Jenis Makanan

Tabel 6 Distribusi frekuensi pengetahuan ibu tentang jenis makanan di Rumah Sakit TK. II Putri Hijau Medan

\begin{tabular}{cccc} 
No & Jenis Makanan & Frekuensi & Persentase (\%) \\
\hline 1 & Kurang & 38 & $28.1 \%$ \\
2 & Cukup + Baik & 97 & $71.9 \%$ \\
\hline & Total & $\mathbf{1 3 5}$ & $\mathbf{1 0 0 . 0 \%}$ \\
\hline
\end{tabular}

Deskripsi Pengetahuan Ibu Tentang Jadwal Makan

Tabel 7 Distribusi frekuensi pekerjaan ibu yang memiliki balita di Rumah Sakit TK. II Putri Hijau Medan

\begin{tabular}{cccc}
\hline \multirow{2}{*}{ No } & Jadwal Makan & Frekuensi & Persentase (\%) \\
\hline 1 & Kurang & 45 & $33.3 \%$ \\
2 & Cukup + Baik & 90 & $66.7 \%$ \\
\hline & Total & $\mathbf{1 3 5}$ & $\mathbf{1 0 0 . 0 \%}$ \\
\hline
\end{tabular}

Deskripsi Pengetahuan Ibu Tentang Pola Makan Balita

Tabel 8 Distribusi frekuensi pengetahuan ibu tentang pola makan balita di Rumah Sakit TK. II Putri Hijau Medan

\begin{tabular}{cccc}
\hline No & Pola Makan Balita & Frekuensi & Persentase (\%) \\
\hline 1 & Kurang & 30 & $22.2 \%$ \\
2 & Cukup + Baik & 105 & $77.8 \%$ \\
\hline & Total & $\mathbf{1 3 5}$ & $\mathbf{1 0 0 . 0 \%}$ \\
\hline
\end{tabular}

Deskripsi Status Gizi Balita

Tabel 9 Distribusi frekuensi status gizi balita di Rumah Sakit TK. II Putri Hijau Medan

\begin{tabular}{cccc} 
No & Pola Makan Balita & Jumlah & Persentase (\%) \\
\hline 1 & Buruk & 22 & $16.3 \%$ \\
2 & Kurang & 87 & $64.4 \%$
\end{tabular}




\begin{tabular}{cccc} 
Baik & 26 & $19.3 \%$ \\
\hline Total & $\mathbf{1 3 5}$ & $\mathbf{1 0 0 . 0 \%}$ \\
\hline
\end{tabular}

\section{Hubungan Pengetahuan Ibu Tentang Frekuensi Makan Dengan Status Gizi Balita}

Tabel 10 Tabulasi silang pengetahuan ibu tentang frekuensi makan dengan status gizi balita di Rumah Sakit TK. II Putri Hijau Medan

\begin{tabular}{|c|c|c|c|c|c|c|c|c|}
\hline \multirow{3}{*}{$\begin{array}{l}\text { Pengetahuan } \\
\text { ibu tentang } \\
\text { frekuensi } \\
\text { makan }\end{array}$} & \multicolumn{6}{|c|}{ Status gizi balita } & \multirow{2}{*}{\multicolumn{2}{|c|}{ Total }} \\
\hline & \multicolumn{2}{|c|}{ Gizi buruk } & \multicolumn{2}{|c|}{ Gizi kurang } & \multicolumn{2}{|c|}{ Gizi baik } & & \\
\hline & $\mathbf{F}$ & $\%$ & $\mathbf{F}$ & $\%$ & $\mathbf{F}$ & $\%$ & $\mathbf{F}$ & $\%$ \\
\hline Kurang & 17 & $12.6 \%$ & 19 & $14.1 \%$ & 2 & $1.5 \%$ & 38 & $28.1 \%$ \\
\hline Cukup + baik & 5 & $3.7 \%$ & 68 & $50.4 \%$ & 24 & $17.8 \%$ & 97 & $71.9 \%$ \\
\hline Total & 22 & $16.3 \%$ & 87 & $64.4 \%$ & 26 & $19.3 \%$ & 135 & $100.0 \%$ \\
\hline
\end{tabular}

Dari tabel 4.10 dari sebuah hasil decode dapat diketahui bahwa dari 38 orang ibu $(28,1 \%)$ yang memiliki pengetahuan yang kurang tentang frekuensi makan terdapat 17 balita status gizi buruk (12.6\%), 19 balita status gizi krang (14,1\%), 2 balita status gizi baik (1,5\%), sedangkan 97 orang ibu $(71,9 \%)$, yang memiliki pengetahuan cukup + baik tentang frekuensi makan terdapat 5 balita status gizi buruk (3,7\%), 68 balita tatus gizi kurang $(50,4 \%), 24$ balita status gizi baik $(17,8 \%)$.

Hasil uji statistic chi square menunjukkan bahwa nilai $\mathrm{p}=0,000$ artinya ada hubngan pengetahuan ibu tentang frekuensi makan balita dengan status gizi balita dan hubungan searah dimana semakin tinggi pengetahuan ibu tentang frekuensi makan, maka status gizi balita semakin baik.

\section{Hubungan Pengetahuan Ibu Tentang Porsi Makanan Dengan Status Gizi Balita}

Dari hasil recode dibawah ini dapat diketahui bahwa dari 47 orang ibu $(34,8 \%)$ yang memiliki pengetahuan kurang tentang porsi makanan terdapat 15 balita status gizi buruk $(11,1 \%), 30$ balita status gizi kurang $(22,2 \%), 2$ balita status gizi baik $(1,5 \%)$, sedangkan 88 orang ibu $(65,2 \%)$ yang memiliki pengetahuan cukup+baik tentang porsi makanan terdapat 7 balita status gizi buruk (5,2\%), 57 balita status gizi kurang $(42,2 \%), 24$ balita status gizi baik $(17,8 \%)$.

Tabel 11 Tabulasi silang pengetahuan ibu tentang porsi makanan dengan status gizi balita di Rumah Sakit TK. II Putri Hijau Medan

\begin{tabular}{lcccccccc} 
& \multicolumn{9}{c}{ Status gizi balita } & \multicolumn{2}{c}{ Total } \\
\cline { 2 - 7 } $\begin{array}{l}\text { Pengetahuan } \\
\text { ibu tentang } \\
\text { frekuensi } \\
\text { makan }\end{array}$ & Gizi buruk & \multicolumn{2}{c}{ Gizi kurang } & Gizi baik & & \\
\cline { 2 - 7 } & F & $\%$ & F & $\%$ & F & $\%$ & F & $\%$ \\
\hline Kurang & 15 & $11.1 \%$ & 30 & $22.2 \%$ & 2 & $1.5 \%$ & 47 & $34.8 \%$ \\
Cukup + baik & 7 & $5.2 \%$ & 57 & $42.2 \%$ & 24 & $17.8 \%$ & 88 & $65.2 \%$
\end{tabular}




\begin{tabular}{lllllllll}
\hline Total & 22 & $16.3 \%$ & 87 & $64.4 \%$ & 26 & $19.3 \%$ & 135 & $100.0 \%$ \\
\hline$P=0,000$ & & & &
\end{tabular}

\section{Hubungan Pengetahuan Ibu Tentang Jenis Makanan Dengan Status Gizi Balita}

Hasil uji statistik chi-square menunjukkan bahwa nilai $\mathrm{p}=0,000$ artinya ada hubungan pengetahuan ibu tentang jenis makanan dengan status gizi balita dan hubungan searah dimana semakin tinggi pengetahuan ibu tentang jenis makanan balita maka status gizi balita semakin baik.

Tabel 12 Tabulasi silang pengetahuan ibu tentang jenis makanan dengan status gizi balita di Rumah Sakit TK. II Putri Hijau Medan

\begin{tabular}{|c|c|c|c|c|c|c|c|c|}
\hline \multirow{3}{*}{$\begin{array}{l}\text { Pengetahuan } \\
\text { ibu tentang } \\
\text { frekuensi } \\
\text { makan }\end{array}$} & \multicolumn{6}{|c|}{ Status gizi balita } & \multirow{2}{*}{\multicolumn{2}{|c|}{ Total }} \\
\hline & \multicolumn{2}{|c|}{ Gizi buruk } & \multicolumn{2}{|c|}{ Gizi kurang } & \multicolumn{2}{|c|}{ Gizi baik } & & \\
\hline & $\mathbf{F}$ & $\%$ & $\mathbf{F}$ & $\%$ & $\mathbf{F}$ & $\%$ & $\mathbf{F}$ & $\%$ \\
\hline Kurang & 13 & $9.6 \%$ & 23 & $17.0 \%$ & 2 & $1.5 \%$ & 38 & $28.1 \%$ \\
\hline Cukup + baik & 9 & $6.7 \%$ & 64 & $47.4 \%$ & 24 & $17.8 \%$ & 97 & $71.9 \%$ \\
\hline Total & 22 & $16.3 \%$ & 87 & $64.4 \%$ & 26 & $19.3 \%$ & 135 & $100.0 \%$ \\
\hline
\end{tabular}

Hubungan Pengetahuan Ibu Tentang Jadwal Makan Dengan Status gizi Balita

Dari tabel 13 hasil recode dibawah ini dapat diketahui bahwa dari 45 orang ibu (33,3\%) yang memiliki pengetahuan kurang tentang jadwal makan terdapat 14 balita status gizi buruk $(10,4 \%)$, balita status gizi kurang (18,5\%), 6 balita status gizi baik (4,4\%), sedangkan 90 orang ibu $(66,7 \%)$ yang memiliki pengetahuan cukup+baik tentang jadwal makan terdapat 8 balita status gizi buruk (5,9\%), 62 balita status gizi kurang (45,9\%), 20 balita status gizi baik $(14,8 \%)$.

Hasil uji statistik chi-square menunjukkan bahwa nilai $\mathrm{p}=0,000$ artinya ada hubungan pengetahuan ibu tentang jadwal makan dengan status gizi balita dan hubungan searah dimana semakin tinggi pengetahuan ibu tentang jadwal makan balita maka status gizi balita semakin baik.

Tabel 13 Tabulasi silang pengetahuan ibu tentang jadwal makan dengan status gizi balita di Rumah Sakit TK. II Putri Hijau Medan

\begin{tabular}{lcccccccc}
\hline \multirow{2}{*}{$\begin{array}{l}\text { Pengetahuan } \\
\text { ibu tentang } \\
\text { frekuensi } \\
\text { makan }\end{array}$} & \multicolumn{9}{c}{ Gizi buruk } & \multicolumn{2}{c}{ Gizi kurang } & \multicolumn{2}{c}{ Gizi baik } & \multicolumn{2}{c}{ Total } \\
\cline { 2 - 7 } & F & $\%$ & F & $\%$ & F & $\%$ & F & $\%$ \\
\hline Kurang & 14 & $10.4 \%$ & 25 & $18.5 \%$ & 6 & $4.4 \%$ & 45 & $33.3 \%$ \\
Cukup + baik & 8 & $5.9 \%$ & 62 & $45.9 \%$ & 20 & $14.8 \%$ & 90 & $66.7 \%$
\end{tabular}




\begin{tabular}{ccccccccc}
\hline Total & 22 & $16.3 \%$ & 87 & $64.4 \%$ & 26 & $19.3 \%$ & 135 & $100.0 \%$ \\
\hline$P=0,004$ & & & &
\end{tabular}

\section{Hubungan Pengetahuan Ibu Tentang Pola Makan Dengan Status gizi Balita}

Dari tabel 4.14 hasil recode dibawah ini dapat diketahui bahwa dari 30 orang ibu $(22,2 \%)$ yang memiliki pengetahuan kurang tentang pola makan terdapat 11 balita status gizi buruk $(8,1 \%), 15$ balita status gizi kurang $(11,1 \%), 4$ balita status gizi baik $(3,0 \%)$, sedangkan 105 orang ibu $(77,8 \%)$ yang memiliki pengetahuan cukup+baik tentang jadwal makan terdapat 11 balita status gizi buruk $(8,1 \%), 72$ balita status gizi kurang $(53,3 \%), 22$ balita status gizi baik $(16,3 \%)$.

Hasil uji statistik chi-square menunjukkan bahwa nilai $\mathrm{p}=0,003$ artinya ada hubungan pengetahuan ibu tentang pola makan balita dengan status gizi balita dan hubungan searah dimana semakin tinggi pengetahuan ibu tentang jadwal makan balita maka status gizi balita semakin baik.

Tabel 14 Tabulasi silang pengetahuan ibu tentang pola makan dengan status gizi balita di Rumah Sakit Tk II Putri hijau Medan tahun

\begin{tabular}{|c|c|c|c|c|c|c|c|c|}
\hline \multirow{3}{*}{$\begin{array}{l}\text { Pengetahuan } \\
\text { ibu tentang } \\
\text { frekuensi } \\
\text { makan }\end{array}$} & \multicolumn{6}{|c|}{ Status gizi balita } & \multirow{2}{*}{\multicolumn{2}{|c|}{ Total }} \\
\hline & \multicolumn{2}{|c|}{ Gizi buruk } & \multicolumn{2}{|c|}{ Gizi kurang } & \multicolumn{2}{|c|}{ Gizi baik } & & \\
\hline & $\mathbf{F}$ & $\%$ & $\mathbf{F}$ & $\%$ & $\mathbf{F}$ & $\%$ & $\mathbf{F}$ & $\%$ \\
\hline Kurang & 11 & $8.1 \%$ & 15 & $11.1 \%$ & 4 & $3.0 \%$ & 30 & $22.2 \%$ \\
\hline Cukup + baik & 11 & $8.1 \%$ & 72 & $53.3 \%$ & 22 & $16.3 \%$ & 105 & $77.8 \%$ \\
\hline Total & 22 & $16.3 \%$ & 87 & $64.4 \%$ & 26 & $19.3 \%$ & 135 & $100.0 \%$ \\
\hline
\end{tabular}

\section{Pembahasan}

\section{Hubungan Pengetahuan Ibu Tentang Frekuensi Makan Dengan Status gizi Balita}

Dari hasil penelitian bahwa dari $28.1 \%$ ibu yang memiliki pengetahuan kurang tentang frekuensi makan ada $12.6 \%$ balita status gizi buruk $13.3 \%$ balita status gizi kurang $2.2 \%$ balita status gizi baik sedangkan $71.9 \%$ ibu yang memiliki pengetahuan cukup+baik tentang frekuensi makan ada $3.7 \%$ balita status gizi buruk $50,4 \%$ balita status gizi kurang $17,8 \%$ balita status gizi baik.

Hasil uji statistik chi-square menunjukkan bahwa hubungan pengetahuan ibu tentang frekuensi makan dengan status gizi balita dimana nilai $p=0,000$. Menurut Sari (2018) dalam penelitiannya tentang Hubungan Pengetahuan Ibu tentang Pola Pemberian Makan dengan Status Gizi Balita di Wilayah Kerja Puskesmas Gapura Kabupaten Sumenep menyatakan bahwa Pengetahuan ibu mengenai pola pemberian makan sebagai sumber data primer diperoleh melalui wawancara dengan orang tua atau keluarga balita. Data dianalisis menggunakan uji statistik Chi-square. Hasil penelitian menyatakan bahwa terdapat hubungan antara pengetahuan pola pemberian makan dengan status gizi balita $(\mathrm{p}<0,05)$.

Ini berbeda dengan hasil recode pengetahuan ibu tentang frekuensi makan dengan status gizi balita, dimana hasil yang didapatkan bahwa ibu yang memiliki pengetahuan cukup+baik ada balita yang mengalami status buruk. Pengetahuan ibu ini dapat dipengaruhi oleh faktor lain seperti pekerjaan ibu yang mayoritas petani, hal ini sesuai dengan yang pendapat Pangaribuan R (2017) dalam penelitiannya, faktor yang mempengaruhi pengetahuan adalah umur, pendidikan, pekerjaan dan informasi. 


\section{Hubungan Pengetahuan Ibu Tentang Porsi Makan Dengan Status Gizi Balita}

Dari hasil penelitian bahwa dari $34,8 \%$ orang ibu yang memiliki pengetahuan kurang tentang porsi makan ada $11,1 \%$ balita status gizi buruk $22,2 \%$ balita status gizi kurang $1,5 \%$ balita status gizi baik sedangkan $65,2 \%$ ibu yang memiliki pengetahuan cukup+baik tentang porsi makan ada $5,2 \%$ balita status gizi buruk $42,2 \%$ balita status gizi kurang $17,8 \%$ balita status gizi baik.

\section{Hubungan Pengetahuan Ibu Tentang Jenis Makanan Dengan jenis Gizi Balita}

Dari hasil penelitian bahwa dari $28,1 \%$ orang ibu yang memiliki pengetahuan kurang tentang jenis makanan ada $9,6 \%$ balita status gizi buruk $17,0 \%$ balita status gizi kurang 1,5\% balita status gizi baik sedangkan $71,9 \%$ ibu yang memiliki pengetahuan cukup+baik tentang porsi makan ada $6,7 \%$ balita status gizi buruk $47,4 \%$ balita status gizi kurang $17,8 \%$ balita status gizi baik.

Bila pengetahuan zat gizi balita terpenuhi. Bila pengetahuan ibu tentang jenis makanan yang bergizi masih kurang maka pemberian makanan untuk balita dipilih jenis bahan makanan yang hanya dapat mengenyangkan perut saja tanpa memikirkan apakah itu bergizi atau tidak, sehingga kebutuhan energi dan zat gizi balita tidak terpenuhi.

Ini berbeda dengan hasil recode pengetahuan ibu tentang jenis makanan dengan status gizi balita , dimana hasil yang didapatkan bahwa ibu yang memiliki pengetahuan cukup+baik ada balita yang mengalami status buruk. Pengetahuan ibu ini dapat dipengaruhi oleh faktor lain seperti pekerjaan ibu yang mayoritas petani, hal ini sesuai dengan yang dikemukakan oleh Notoadmodjo (2012), pekerjaan bahwa faktor yang mempengaruhi pengetahuan adalah umur, pendidikan, pekerjaan dan informasi.

\section{Hubungan Pengetahuan Ibu Tentang Jadwal Makan Dengan Status Gizi Balita}

Dari hasil penelitian bahwa dari 33,3\% orang ibu yang memiliki pengetahuan kurang tentang jadwal makan ada $10,4 \%$ balita status gizi buruk $18,5 \%$ balita status gizi kurang $4,4 \%$ balita status gizi baik sedangkan $66,7 \%$ ibu yang memiliki pengetahuan cukup+baik tentang porsi makan ada $5,9 \%$ balita status gizi buruk $45,9 \%$ balita status gizi kurang $14,8 \%$ balita status gizi baik.

Ini berbeda dengan hasil recode pengetahuan ibu tentang jadwal makan dengan status gizi balita , dimana hasil yang didapatkan bahwa ibu yang memiliki pengetahuan cukup+baik ada balita yang mengalami status buruk. Pengetahuan ibu ini dapat dipengaruhi oleh faktor lain sseperti pekerjaan ibu yang mayoritas petani, hal ini sesuai dengan yang dikemukakan oleh Notoadmodjo (2012) pekerjaan bahwa faktor yang mempengaruhi pengetahuan adalah umur, pendidikan, pekerjaan dan informasi. Begitu juga hasil penelitian lainnya menyatakan bahwa Pendidikan dan jenis pekerjaan berpengaruh positif dan signifikan terhadap pengetahan (Sulaiman, 2019).

\section{Hubungan Pengetahuan Ibu Tentang Pola Makan Dengan Status Gizi Balita}

Dari hasil penelitian bahwa dari $22,2 \%$ orang ibu yang memiliki pengetahuan kurang tentang pola makan balita terdapat $8,1 \%$ balita status gizi buruk $11,1 \%$ balita status gizi kurang $3,0 \%$ balita status gizi baik sedangkan $77,8 \%$ ibu yang memiliki pengetahuan cukup+baik tentang pola makan terdapat $8,1 \%$ balita status gizi buruk $53,3 \%$ balita status gizi kurang $16,3 \%$ balita status gizi baik.

Hasil uji statistik chi-square menunjukkan bahwa hubungan pengetahuan ibu tentang jadwal makan dengan status gizi balita dimana nilai $p=0,003$. Hasil penelitian ini juga sesuai dengan penelitian yang dilakukan Oktalinda dan Tribowo (2012) tentang hubungan pengetahuan ibu balita tentang gizi dengan status gizi balita (1-5 tahun) di Posyandu Dusun Modopuro Desa Modopuro Kecamatan Mojosari Mojokerto terhadap 70 orang responden. 
Hasil penelitian tersebut menjelaskan bahwa ada hubungan yang bermakna antar pengetahuan ibu dengan status gizi balita ( $\mathrm{p}$ value 0,001 ).

Kebiasaan pola makan yang baik dan teratur makan kebutuhan energi dan kecukupan gizi bagi tubuh balita akan terpenuhi. Bila kebiasaan pola makan balita tidak baik, maka proses pertumbuhan dan perkembangan fisik balita yang tengah berlangsung akan terganggu. Hal ini sejalan dengan hasil penelitian yang dilakkan oleh Pangaribuan. R (2018) Makin tinggi pendidikan di harapkan makin luas pula pengetahuan seseorang.

Ini berbeda dengan hasil recode pengetahuan ibu tentang jadwal makan dengan status gizi balita dimana hasil yang didapatkan bahwa ibu yang memiliki pengetahuan cukup+baik ada balita yang mengalami status buruk. Pengetahuan ibu ini dapat dipengaruhi oleh faktor lain seperti pekerjaan ibu yang mayoritas petani, hal ini sesuai dengan yang dikemukakan oleh Notoadmodjo (2012), pekerjaan bahwa faktor yang mempengaruhi pengetahuan adalah umur, pendidikan, pekerjaan dan informasi.

\section{KESIMPULAN}

Berdasarkan hasil penelitian mengenai hubungan pengetahuan Ibu Tentang Pola Makanan balita dengan Status Gizi Balita sebagai berikut:

1. Ada hubungan pengetahuan ibu tentang frekuensi makan balita dengan status gizi balita $(\mathrm{p}<0,05)$

2. Ada hubungan pengetahuan ibu tentang porsi makan balita dengan status gizi balita $(\mathrm{p}<0,05)$

3. Ada hubungan pengetahuan ibu tentang jenis makan balita dengan status gizi balita

4. Ada hubungan pengetahuan ibu tentang jadwal makan balita dengan status gizi balita $(\mathrm{p}<0,05)$

5. Ada hubungan pengetahuan ibu tentang pola makan balita dengan status gizi balita $(\mathrm{p}<0,05)$

\section{REFERENSI}

Dahlan, S, M, 2019, Statistika Kedokteran Dan Kesehatan, Edisi 3, Jakarta. Salemba Medika Hidayat, 2018, Metodologi penelitian Keperawatan dan kesehatan, Salemba Medika, Jakarta. Iranto, Kus, Kusno Waluyo, 2010, Gizi dan Pola Hidup Sehat, Yrama Widya, Jakarta.

Irianto, Djoko Pekik, 2010, Panduan Gizi Lengkap, Edisi I Penerbit Andi Yogyakarta.

Liputan 6.com (2018) Stunting Ancaman hilangnya satu generasi

Notoatmodjo, 2012, Pendidikan Dan Perilaku Kesehatan, Penerbit Rineka Cipta.Jakarta.

Pangaribuan, R., Siagian, M. T., \& Sirait, A. (2018). Pengaruh Media Pendidikan Kesehatan Terhadap Pengetahuan Bantuan Hidup Dasar (BHD)(Studi Eksperimen Pada Perawat Pelaksana di Rumah Sakit TK. II Putri Hijau Medan Tahun 2017). JUMANTIK (Jurnal Ilmiah Penelitian Kesehatan), 3(1), 101-108.

Pangaribuan, R (2018) Kebutuhan Dasar Manusia Aplikasi Konsep Dan Kompetensi Keperawatan, Perdana Medika, Medan.

Prawirohartono, 2018, Anakku Sulit makan, Gajah Mada University Press, Jakarta.

Riskesdas, (2013), Pusat Data Dan Informasi Departemen Kesehatan Republik Indonesia, Jakarta..

Sari nirmala, Ratnawati L (2018). Hubungan Pengetahuan Ibu tentang Pola Pemberian Makan dengan Status Gizi Balita di Wilayah Kerja Puskesmas Gapura Kabupaten Sumenep. DOI : 10.2473/amnt.v2i2.2018.182-188

Sentot Handoko, Sp.GK , 2020 https://www.emc.id/id/care-plus/gizi-seimbang-untuk-gayahidup-yang-sehat 
Sulaiman \& Angraini (2019) Tingkat Pengetahuan Siswa Tentang Fisioterapi Di Smk Negeri 2 Sibolga Kota Sibolga, Amaliah: Jurnal pengabdian masyarakat Vol. 3. No.2

Susanti R, Indriati (2014) Hubungan Pengetahuan Ibu Tentang Gizi Dengan Status Gizi Anaka Usia 1-3 Tahun

Tim dapur sehat (2018), Menu Sehat Untuk Balita, Kawan Pustaka, Jakarta.

Tribowo (2012) Hubungan pengetahuan ibu balita tentang gizi dengan status gizi balita (1-5 tahun) di Posyandu Dusun Modopuro Desa Modopuro Kecamatan Mojosari Mojokerto

https://www.sehatq.com/artikel/pengertian-gizi-seimbang-dan-pedoman-umumnya-yang-bisaanda-praktikkan

https://hellosehat.com/parenting/kesehatan-anak/stunting-adalah-anak-pendek/ 